\title{
APPLICATION OF ASSET REVALUATION BY THE PUBLIC ASSESSMENT OFFICE: A REFLECTION OF SHARIA ACCOUNTING, SHARI'AH ENTERPRISE THEORY
}

\author{
Tatang Fatah Musthafa ${ }^{1}$, Iwan Triyuwono ${ }^{2}$, Noval Adib $^{3}$ \\ ${ }^{1,2,3}$ Faculty of Economics and Business -Brawijaya University \\ Email: tfattahmusthafa@gmail.com
}

\begin{abstract}
Abstrcat: $\quad$ The purpose of this research is to have a deeper look at the practice of public appraisers at the Public Appraisal Services Office (KJPP) X, in carrying out the revaluation of fixed assets, mainly related to Islamic values by using Shari'ah Enterprise Theory. The research method used a qualitative approach with case study analysis techniques. The results of this study indicate that the scope of the KJPP assignment is still not in accordance with the Shari'ah Enterprise Theory
\end{abstract}

\section{Preliminary}

The development of human needs is increasing day by day. In line with this, the role of accounting is very large to influence all matters related to these needs. However, the current implementation of accounting practices tends to be secular in nature and contrary to religious teachings, especially Islam. The role of parties related to accounting is no less significant, for example this research is related to the role of public appraisers who have obtained permission from the Minister of Finance of the Republic of Indonesia Number 101 / PMK.01 / 2014 to provide services as an asset revaluation appraiser.

This secular accounting system contradicts the Islamic concept. In general, the contradictions of conventional accounting from an Islamic perspective are; First, conventional accounting does not recognize the existence of religious and metaphysical interference and places humans as absolute power owners in decision-making and its main objective is to achieve maximum profit, in contrast to accounting based on sharia which is based on sharia rules that come from Allah and associated with worship and blessings and there is an accountability to God. Second, the basic value of conventional accounting which emphasizes the concept of self-interest rather than social interest. Third, the concept of conventional accounting only sees humans as homo economicus while in Islam, humans are not only homo economicus but also homo ethicus and homo religious.

Criticism in the asset revaluation process, for example, is the use of principles, the valuation approach and fair value itself. In this case, the principle of the Highest and Best Use (HBU) is one of the main principles, where it is discussed in the Concepts and General Principles of Assessment and a separate chapter, namely the Guidelines for the Implementation of Indonesian Assessment. HBU principles have 4 main principles, namely legal permissibility, physical possibility, financial feasibility, and maximum profitability (Appraisal Institute, 2008, SPI Edition VII-2018, PPPI). Grasskamp's criticism of HBU (Vandell and Carter in Essay in Honor of James Graaskamp, 2000) includes both theoretical and practical criticism. Theoretically, Grasskamp's criticism refers to the notion of HBU that should be interpreted in the context of most fitting use or most probable use which is consistent with the definition of time. The HBU concept should combine elements of uncertainty and risk considerations as well as being dynamic (developing over time). Grasskamp's criticism in the context of practice is that HBU does not represent the best service for stakeholders, 
International Journal of Economics, Business and Accounting Research (IJEBAR)

Peer Reviewed - International Journal

Vol-4, Issue-3, 2020 (IJEBAR)

E-ISSN: 2614-1280 P-ISSN 2622-4771

https://jurnal.stie-aas.ac.id/index.php/IJEBAR

especially the community, in practice HBU is interpreted narrowly to only refer to the private sector. Grasskamp emphasized that HBU is a concept that contains elements of personal rather than social benefits.

Meanwhile, criticism of the approach taken is generally found in the revenue approach and the cost approach. The Income Approach considers the income an asset will generate over its useful life and calculates value through a capitalization process. Capitalization represents the conversion of income to capital using an appropriate discount rate. Cash flows can be obtained from the revenue of a contract or several contracts or not from contracts; for example, the anticipated gain from using or owning an asset. (18.2 KPUP, KEPI \& SPI VII Edition - 2018). Capitalization in this approach is closely related to the Capital Asset Pricing Model (CAPM), which also reaps the pros and cons as expressed by Levy (2010), between using the CAPM or the Roy Model.

Asset revaluation is closely related to fair value, which is one of the standards contained in the International Financial Reporting Standards (IFRS). Because only IFRS allows appreciation of the value of fixed assets through the asset revaluation procedure. (Yoo et al, 2017) The main objective of revaluation of fixed assets is so that fixed assets reflect fair value in the financial statements. Previous research has suggested that companies, both private and government-owned, undertake asset revaluations to improve their financial position, providing an indication of their future prospects and financial health (Brown et al. 1992; Whittred and Chan 1992; Easton et al. 1993. ; Cotter and Zimmer 1995; Gaeremynck and Veugelers 1999; Lin and Peasnell 2000; Barlev et al. 2007). Lin and Peasnell (2000) found several factors that underlie asset revaluation including obtaining a larger loan amount, the threat of takeover, issuance of bonus shares, possible breach of debt covenants, labor strikes, decreased operating cash flow, growth prospects, and liquidity.

The existence of fixed asset revaluation also has an impact on the company's strength in making negotiations related to loan contracts with lenders (Asad \& Qadeer, 2014). In addition, the reason for carrying out asset revaluation is a decrease in operating cash flows. The company's loan capacity depends not only on leverage but also on the company's ability to repay loans (Bashir and Asad, 2018). A decrease in cash flow from operations can make lenders doubt the company's liquidity (Asad and Farooq, 2009). An increase in asset revaluation can be an effective solution to reduce earnings reporting by increasing depreciation costs from asset revaluation (Heidar, 2016; 2017). Information asymmetry is also a significant reason for asset revaluation. Information asymmetry occurs when external users of the company's financial statements are not provided with correct information due to differences in actual and reported values in the financial statements (Wali, 2015). Information asymmetry affects management in making decisions regarding the timing of asset revaluation (Tabari and Adi, 2014).

In general, the work of public appraisers is not much different from that of accountants, as explained in the background chapter, it is in accordance with the materiality of a value to get the maximum gain and the smallest loss. The problem that exists is how is the practice of the scope of assignment, implementation and reporting of asset revaluation in KJPP X based on the point of view of Shari'ah Enterprise Theory ?. Therefore, the purpose of this study is to examine more deeply the practice of public appraisers at the Public Appraisal Service Office (KJPP) X in carrying out fixed asset revaluations, primarily related to sharia values using the Shari'ah Enterprise Theory.

\section{Literature Review}

Revaluasi Aset

Revaluation of fixed assets is a revaluation of the value of assets and adjusts the value of these assets based on their current fair value (Brown et al, 1992). Fixed assets are depreciated based on 
International Journal of Economics, Business and Accounting Research (IJEBAR)

Peer Reviewed - International Journal

Vol-4, Issue-3, 2020 (IJEBAR)

E-ISSN: 2614-1280 P-ISSN 2622-4771

https://jurnal.stie-aas.ac.id/index.php/IJEBAR

their estimated useful lives and residual values. The estimated useful lives and residual values will change from time to time, for this reason the company needs to conduct a revaluation with the aim of knowing the value of these assets based on the relevant current fair value. Asset revaluation can occur if fixed assets experience an increase or decrease in market value due to devaluation, which causes the value of the fixed assets to no longer show fair value.

Fixed asset evaluation will provide more relevant information for investors for decision making. Asset revaluation is something that requires professional judgment in determining the relevant value of a company's assets which will be used by stakeholders in making important decisions. To be able to have professional judgment, an accountant must have knowledge, skills and ethics because if they do not have these three things, the professional judgment taken is not correct.

The legal basis for Public Appraisers and Public Appraisal Services Office (KJPP) in carrying out asset revaluation is contained in several regulations, namely Regulation of the Minister of Finance of the Republic of Indonesia Number 101 / PMK.01 / 2014 concerning Public Appraisers, Law Number 40 of 2007 concerning Limited Liability Companies as Appraiser of Share Deposits, Law number 8 of 1995 concerning Capital Market as a Capital Market Supporting Professional, Law Number 2 of 2012 concerning Land Acquisition for Development for Public Interest as Appraiser of assets that are objects of land acquisition, as well as Presidential Regulation number 8 of 2006 concerning Guidelines for the Implementation of Government Goods / Services Procurement.

In the asset revaluation process, KJPP is obliged to comply with the Indonesian Assessment Standard (SPI) VII Edition of 2018. In the implementation process, SPI asks the Public Appraiser and KJPP to carry out 3 processes, namely the Scope of Assignment process (SPI Edition VII 2018, SPI 103), the process implementation (SPI Edition VII 2018 - SPI 104) in which there is an asset valuation approach, namely the Market Approach, the Income Approach, and the Cost Approach., and the final process is the reporting process (SPI Edition VII - 2018, SPI 105). Public Appraisers and KJPP are also asked to follow the General Assessment Concepts and Principles (KPUP).

The cost approach produces an indication of value using economic principles, where the buyer will not pay for an asset more than the cost to acquire an asset with the same or equivalent use, at the time of purchase or construction (19.1 KPUP, Indonesian Valuation Code of Ethics (KEPI) and Valuation Standards. Indonesia (SPI) Edition VII - 2018). This approach is stated to have several weaknesses and limitations, namely this approach is not comprehensive (Zyla, 2009), cannot be applied to property with business value (Korpacz, 1992), and the results do not reflect the actual property value (Iwan, 1993).

The use of fair value is also claimed as an opportunistic form of a company in presenting its financial statements which will make it possible for users of financial statements to make wrong decisions (Livne and McNicholas, 2009) and this shows that the use of fair value can provide opportunities for creative accounting, namely by manipulating reports. Finance as needed and for corporate opportunistic purposes (Dunk and Kilgore, 2003; Fatima, 2002). Furthermore Krumwiede (2008) explains that even though fair value is intended to overcome the weaknesses of historical cost, the opportunity for opportunistic occurrence is shown by the dishonesty of managers or accountants who can take advantage of the assessments and estimates used in the manipulation process and play the desired income figures.

The reporting concept based on true and fair view (TFV) is a basic concept developed as a framework in accounting reporting standards. The application of fair value is still controversial. One of the IAS 102 standards related to True And Fair View Override (TFVO) is a matter of 
International Journal of Economics, Business and Accounting Research (IJEBAR)

Peer Reviewed - International Journal

Vol-4, Issue-3, 2020 (IJEBAR)

E-ISSN: 2614-1280 P-ISSN 2622-4771

https://jurnal.stie-aas.ac.id/index.php/IJEBAR

debate. Based on research by Gearin and Khandelwal (1995), TFVO has many disadvantages, because basically TFVO is very subjective and allows abuse. This argument is in line with Healy and Wahlen (1999) that companies can do creative accounting, especially when companies are faced with difficulties experienced by the company, for example, companies need large financing. Furthermore Gearin and Khandelwal (1995) say that even the use of TFVO has an impact on the low consistency, reliability and comparability of financial statements, and will have an impact on the decision making of users of financial statements.

\section{Concept in Shari'ah Enterprise Theory}

Sharia values contained in Islamic teachings are not only at the normative level which discusses morality alone. Islam is a religion of charity so that the interpretation must move from normative to factual theoretical science. Where amar ma'ruf nahi munkar (Hidayat, 2015) as the main objective of sharia to bring goodness and to prevent damage will be achieved. In line with this, Triyuwono (2013) states that with Islam, the blessings for the people of all nature will occur. In his view, Islam states that essential life is the eternal afterlife, but still does not rule out the life of the world, Allah SWT says in Q.S Al Qashash verse 77:

"But seek the abode of the Hereafter in that which Allah hath given thee and neglect not thy portion of the world, and be thou kind even as Allah hath been

kind to thee, and seek not corruption in the earth; lo! Allah loveth not corrupters"

The development of sharia accounting that is not inferior to conventional accounting, Shari'ah Enterprise Theory which is later shortened to SET is a metaphor which basically has a balance character. In general, Triyuwono (2000) explains that the balance in question is the balance between masculine and feminine values. SET is an enterprise theory that has been internalized with Islamic values in order to produce a transcendental and more humanist theory. According to Triyuwono (2003) SET is able to accommodate the plurality of society (stakeholders). This is because the SET concept shows that economic power is no longer in one hand (shareholders), but in many hands, namely stakeholders. Therefore, this SET is more appropriate for an economic system based on sharia values.

The determination of fair value in the value added report is not sufficient as Islamic accounting information because it does not provide room for halal consideration (Mulawarman, 2006a). The report is concerned only with the distribution aspect of economic resources (Hameed and Yaya, 2003). Accountability in value added reports used by accountants is also not based on sharia enterprise theory (Triyuwono 2002b). The intervention of one of the parties with an interest in determining fair value can also cause the recording of resources for the determination and distribution of added value which does not provide certainty for reducing usury (interest).

Mulawarman added that in terms of shariah enterprise theory, business processes including asset revaluation in the accounting scope must fulfill two main aspects, namely quantitative and qualitative. The quantitative aspect consists of financial, social and environmental accountability activities, while the qualitative aspect consists of the halal-thayib-usury-free aspect. If you look further at SET, Triyuwono (2007) states that SET is the basis for idealistic Islamic accounting which has the basic assumption of being khalifatullah 'fil ardh (God's representative on earth). Mulawarman (2006a) explains that the basic assumption of human being apart from being khalifatullah 'fil ardh is also as abd' Allah (the concept of human obedience and submission to Allah). The use of these two assumptions cannot be found in the KJPP because the form of appraiser (appraiser) accountability is only to the assignor (accountant and company) and there is no 
International Journal of Economics, Business and Accounting Research (IJEBAR)

Peer Reviewed - International Journal

Vol-4, Issue-3, 2020 (IJEBAR)

E-ISSN: 2614-1280 P-ISSN 2622-4771

https://jurnal.stie-aas.ac.id/index.php/IJEBAR

accountability consideration in the social environment, even the most important is accountability to Allah SWT.

In line with Triyuwono (2000, 2003), Purwitasari (2011) also explains that SET can be said to be a social integration which originates from an emancipatory interest in freeing knowledge that is always trapped in the material world into knowledge that also considers non-material aspects. The non-material aspects in question are spiritual aspects or divine values. The essence of SET is a result of self-reflection which seeks to understand that apart from rational action, which is the basic action in human relations with nature, as well as acts of communication in relationships with others as objects there are other basic actions related to the relationship between humans and their creators. SET relates to Allah as the main source, because He is the sole and absolute owner.

\section{Research Methods}

\section{Research design}

This research is a qualitative research. The paradigm used in this research is the interpretive paradigm. Based on the topics and research objectives that researchers have described in the previous chapter, this research uses a case study approach.

This research was conducted in the city of Malang with the object of research using the Public Appraisal Service Office (KJPP) X. The reason for this research being conducted at KJPP is because the focus and purpose of this research is related to the revaluation of fixed assets and the reasons why it was carried out at KJPP X in the city. Malang because the existence of KJPP in Indonesia has a limited number and based on legal competence, KJPP X in Malang is expected to have fulfilled the need to answer the questions in this study.

Sources of data used in this study are primary data sources and secondary data sources. Primary data in the form of direct information were obtained from interviews with branch managers of KJPP X, quality control staff and assessment staff. Meanwhile, secondary data was obtained from the report on the results of the revaluation of fixed assets carried out by KJPP $\mathrm{X}$ to their clients. The data source was done by using triangulation validation, so that the data collection techniques used interviews, observation, and documentation.

\section{Research Framework}

Researchers write concepts and formulate ideas to determine research problems, after which the objectives and contributions of solving research problems will be determined. The research problem is viewed from the observations of the researchers observing that the issue of asset revaluation is part of the accounting needs that prioritizes materialism, so this research is designed to see from another point of view according to the religious values in Islamic accounting. The following is a research framework to make it easier to read the research flow presented in Figure 1 to make it easier to understand the preparation of research. 
International Journal of Economics, Business and Accounting Research (IJEBAR)

Peer Reviewed - International Journal

Vol-4, Issue-3, 2020 (IJEBAR)

E-ISSN: 2614-1280 P-ISSN 2622-4771

https://jurnal.stie-aas.ac.id/index.php/IJEBAR

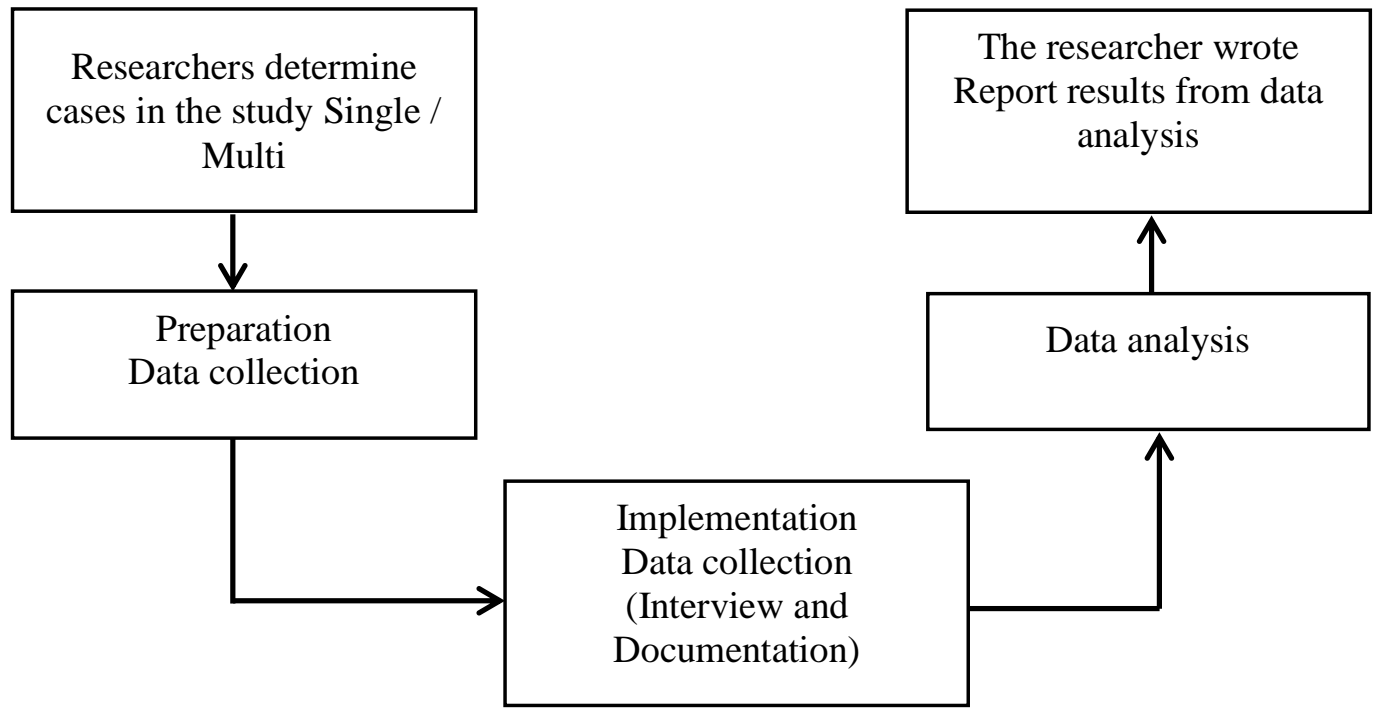

Figure 1 Research Methods Framework

Source: Processed by Researchers (2020)

\section{Data analysis technique}

The case study approach is very suitable for this research because the focus and purpose of this study is to reveal and analyze the fixed asset revaluation events carried out by public appraisers who then researchers have another view of the fixed asset revaluation treatment when compared to religious values and sharia accounting. Shari'ah Enterprise Theory is used for data analysis with a measure that will be used as data analysis in accordance with SET, namely Islamic values, including: 1) Accountability, which can be accounted for in the public interest, 2) Fairness, the principle of implementation in the assessment practice must be fair , 3) Benefit, namely for the benefit of the people or society at large, 4) Falah (Noble), contains the value of glory.

\section{Research Results and Discussion Research result}

This part of the research describes the initial process of asset revaluation, namely the scope of the assignment, in which the scope of the assignment is the basis for starting the asset revaluation work. There are several things that are the subject of discussion, namely 1 . The importance of the scope of the assignment for KJPP 2. SET's view of the scope of the assignment

\section{Discussion}

The appraisal process, from the point of view of a work process, has a definition as a work process to provide a written opinion on the value of an object of assessment in accordance with the Indonesian Assessment Standards (PMK 101/2014)

The definition above provides an initial description that there are four processes, namely, 1 . Work process as a procedure that must be adhered to 2 . Written opinion as a product of the work process 3. Economic value as an output, and 4. Object of the assessment.

The scope of the assignment, as an initial procedure in the appraisal work process, aims to determine the agreed assessment objectives, the level of depth of the investigation, the procedures to be used, the assumptions to be made and the limitations of their use (SPI Edition VII-2018). With 
International Journal of Economics, Business and Accounting Research (IJEBAR)

Peer Reviewed - International Journal

Vol-4, Issue-3, 2020 (IJEBAR)

E-ISSN: 2614-1280 P-ISSN 2622-4771

https://jurnal.stie-aas.ac.id/index.php/IJEBAR

the existence of an appropriate assignment scope, the results of the work process are credible (Suprayoga, 2020). According to Veron (2008), the essence of fair value lies in its relevance, reliability, compatibility and ease of reporting. This of course requires credibility, and credibility starts from the scope of the assignment.

KJPP as the assessor and the Assessor must identify and understand the context of the assignment scope (PMK 101/2014. Article 4.a). The scope of the assignment includes: 1. Identification of Appraiser status 2. Identification of Assigners 3. Identification of Report Users 4. Identification of appraisal objects and ownership 5. Types of currency used 6. Purpose and objectives of the assessment 7. Basis of Value 8. Date of Assessment 9. Level Depth of Investigation 10. Nature and reliable sources of information 11. Special assumptions and assumptions 12. Requirements for approval for publication 13. Confirmation that the assessment is based on SPI 14. Assessment Report 15. Limitation or exclusion of liability to parties other than the Task Giver 16 Statement of data accuracy 17. Appraisal service fees. (SPI Edition VII - 2018). The Branch Manager of KJPP X also confirmed that the work should be started from the scope of the assignment. "Yes, ideally if the scope of assignment and the letter of representation have not been signed, even though the data on the assets to be revalued have already been submitted, we will wait until our contract approval is signed." From KJPP X administrative observations, the scope of assignment for asset revaluation work is all attached in the report archive.

\section{Accountability}

KJPP's responsibility is limited to the Task Giver, report users, accountants, and the person in charge of the report, the informant provides a statement:

"Our report accountability is in accordance with the limits that exist in the scope of the assignment, in general, we are responsible to the Assigner who is usually represented by their accountant."

(Branch Manager KJPP X)

"My responsibility as Quality Control is how the process that occurs in the asset revaluation process is in accordance with the SPI, and in accordance with the habits of the leadership "

(Quality Control / Reviewer KJPP X)

\section{Vertical Accountability: Allah SWT}

Accountability to Allah SWT has not appeared in the scope of the assignment. In fact, Allah SWT as the first and foremost stakeholder, placing Allah SWT in the highest position is the ultimate goal of human life or in other words Allah is the highest stakeholder.

\section{Horizontal Accountability: Direct Stakeholders}

KJPP's attention to Direct Stakeholders is quite big. As a customer driven service company, KJPP X strives to provide services that satisfy the Task Giver in accordance with their vision and mission. In line with this, the emphasis on accountability to Direct Stakeholders can be seen in the SPI, where it provides a specific definition of who is the assignor (SPI 103-3.2), and who is meant by the user of the report (SPI 103-3.3)

\section{Horizontal Accountability: Nature}

The scope of the assignment's attention to nature was not expressed. Nature is an important factor in whether a company runs or not, including KJPP. The company stands on the earth and utilizes scattered natural resources to run the wheels of the company by producing raw materials from nature or providing services to other people by utilizing what is in nature. The form of natural rights 
International Journal of Economics, Business and Accounting Research (IJEBAR)

Peer Reviewed - International Journal

Vol-4, Issue-3, 2020 (IJEBAR)

E-ISSN: 2614-1280 P-ISSN 2622-4771

https://jurnal.stie-aas.ac.id/index.php/IJEBAR

to the company is not in the form of money but the company's concern by preserving nature, not polluting the environment, and other things that can destroy nature (Triyuwono, 2007).

\section{Conclusions}

Based on the results of research on the scope of the KJPP assignment, it can be concluded that the scope of the KJPP asset revaluation assignment is still not in accordance with the SET, where it focuses on horizontal accountability.

\section{Bibliography}

Appraisal Institute, 2008, The Appraisal of Real Estate, Third Edition, Appraisal Institute. Chicago, Illinois.

AOSSG. 2010. Financial Reporting Issues Relating to Islamic Financing. Research Paper

Arikunto, S. (2010). Manajemen Penelitian. Jakarta: Rineka Cipta

Asad, M., \& Farooq, A. (2009). Factors Influencing KSE 100 index/share prices: Paradigm: A Journal of Commerce, Economics, and Social Sciences, 3(1), 34-51.

Asad, M., \& Qadeer, H. (2014). Components of working capital and profitability: A case of fuel and energy sector of Pakistan. Paradigm: A Research Journal of Commerce, Economics, and Social Sciences, 6(1), 100-114.

Arzac, E.R. and Bawa, V.S (1977)., 'Portfolio choice and equilibrium in capital markets with safety-first investors

Bashir, A., \& Asad, M., (2018). Moderating effect of leverage on the relationship between board size, board meeting and performance: A study of textile sector of Pakistan. American Scientific Research Journal for Engineering, Technology, and Sciences, 39(1), 19-29.

Barlev, B., D. Fried, J. Haddad and J. Livnat. 2007. Reevaluation of Revaluations: A Cross-Country Examination of the Motives and Effects on Future Performance.

Basrowi \& Sudikin. (2002). Metode Penelitian Kualitatif Perspektif Mikro. Surabaya: Penerbit Islam Cendekia.

Burrel, G., \& Morgan, G. (1979). Sociological Paradigms and Organisational Analysis: Elements of The Sociology of Corporate Life. London: Heineman Educational Books.

Butt, S.A. and Hassan, A. (2011) 'Valuation and accounting for redeemable corporate capital: An Islamic perspective'

Booth, P. (1993). Accounting in Churches: A Research Framework and Agenda.

Brown, P., Izan, H. Y., \& Loh, A. L. (1992). Fixed Asset Revaluations and Managerial Incentives. Abacus, 28(1), 36-57.

Cotter, J. and I. Zimmer. 1995. Asset Revaluations and Assessment of Borrowing Capacity.

Creswell. J. W. (2007). Qualitative Inquiry \& Research Design: Choosing Among Five Approaches. Second Edition. Thousand oaks: SAGE Publications.

Dotzour, M. G., Grissom, T. V., Liu, C. H., \& Pearson, T. 1990. Highest and best use: The evolving paradigm. Journal of Real Estate Research, 5 (1), 17-32.

Dunk, A. S., \& Kilgore, A. 2003. Top Management Involvement in R\&D Budget Setting: the Importance of Financial Factors, Budget Targets, and R\&D Performance Evaluation. Advances in Management Accounting, 11, 191-

Easton, P., P. Eddey and T. Harris. 1993. An Investigation of Revaluations of Tangible Long-Lived Assets

Emirzon. Joni. 2005. "Kode Etik dan Permasalahan Hukum Jasa Penilai dalam Kegiatan Bisnis di Indonesia”. Jurnal Manajemen \& Bisnis Sriwijaya Vol. 3, No. 5 Juni 2005 
International Journal of Economics, Business and Accounting Research (IJEBAR)

Peer Reviewed - International Journal

Vol-4, Issue-3, 2020 (IJEBAR)

E-ISSN: 2614-1280 P-ISSN 2622-4771

https://jurnal.stie-aas.ac.id/index.php/IJEBAR

Gaeremynck, A. and R. Veugelers. 1999. The Revaluation of Assets as a Signaling Device: A Theoretical and an Empirical Analysis.

Gallhofer, S. \& Haslam, J. (2004). Accounting and liberation theology: Some insights for the project of emancipatory accounting.

Goetzmann, W.N. and Broadie, M. (1992), 'Safety first portfolio choice',

Haider, S.H. et al. (2016) A study on the issues of employment contracts and practices of employment contract in UAE. Paradigm: A Journal Commerce, Economics, and Social Sciences, 10(1), 58-64.

Haider, S.H. et al. (2017). Enterpreneural orientation and business performance of manufacturing sector small and medium scale enterprises of Punjab Pakistan. European Business and Management, 3(2), 21-28.

Hameed, S., Ibrahim, M., \& Rizal, Y. (2005). The emerging issues on the objectives and characteristics of Islamic accounting for Islamic business organizations.

Harling, K. (2002). An Overview of Case Study. This Paper supports a similary titled discussion that Harling Conducted at the Learning Workshop, "Case Studies: Their Future Role in Agricultural and Resource Economics". Long Beach. California. July 27.

Healy, P., dan Wahlen J. 1999. A Review of The Earnings Manajement Literature and Its Implications for Standard Setting. Accounting Horizon 12(4).

Hidayat, R. (2015). Effects Of Service Quality, Customer Trust And Customer Religious Commitment On Customer Satisfaction And Loyalty Of Islamic Banks In East Java. AlIqtishad. 7(2).

Ibrahim, M. Et, All. 2000. Pembelajaran Kooperatif. Surabaya: Universitas Negeri Surabaya Press.

Ibrahim, S. H. M., Wirman, A., Alrazi, B., Nor, M. N. B. M., \& Pramono, S. (2004, April). Alternative Disclosure \& Performance Measures For Islamic Banks. In Second Conference on Administrative Sciences: Meeting the Challenges of the Globalization Age, King Fahd University of Petroleum \& Minerals, Dhahran, Saudi Arabia (pp. 19-21).

Iwan, Gregory A. (1993). "The Cost Approach - Inflexible or Infeasible?"

Korpacz, Peter F. (1992). "Changing Times Call for Revamped Valuation Methods"

Krumwiede, Tim. (2008). Strategic Finance: Why Historical Cost Accounting Make Sense? CPA

Laughlin, RC. (1988). Accounting in its Social Context: An Analysis of the Accounting Systems of the Church of England.

Levy, Haim. (2010). The CAPM is Alive and Well: A Review and Synthesis

Levy, H. and Sarnat, M (1972)., 'Safety first - an expected utility principle',

Lin, Y. C., and Peasnell, K. V., 2000, Fixed Asset Revaluation and Equity Depletion in UK, Journal of Business Finance and Accounting, 27

MacNeal, Kenneth. 1970. Truth in Accounting. University of Pensylvenia.

Milevsky, M.A. (1999), 'Time diversification, safety-first and risk',

Moleong, L. J. (2006). Metode Penelitian Kualitatif Edisi Revisi. Yogyakarta: PT. Remaja Rosdakarya.

Mulawarman, Aji Dedi, Akuntansi Syariah : Teori, Konsep dan Laporan Keuangan, Jakarta: E Publishing Kompany, 2009.

Myers, M. D. (2009). Qualitative Research in Business and Management. London: SAGE Publications.

Purwitasari, Fadilla. (2011). Analisis Pelaporan Corporate Social Responsibility Perbankan Syariah dalam Perspektif Shariah Enterprise Theory: Studi Kasus pada Laporan Tahunan Bank 
International Journal of Economics, Business and Accounting Research (IJEBAR)

Peer Reviewed - International Journal

Vol-4, Issue-3, 2020 (IJEBAR)

E-ISSN: 2614-1280 P-ISSN 2622-4771

https://jurnal.stie-aas.ac.id/index.php/IJEBAR

Syariah Mandiri dan Bank Muamalat Indonesia. Journal of Accounting. Fakultas Ekonomika dan Bisnis, Universitas Diponegoro, Semarang.

Pyle, D.H. and Turnovsky, S.J (1970), 'Safety-first and expected utility maximization in meanstandard deviation portfolio analysis',

Sharpe, I. G., dan R. G. Walker. 1975. Asset Revaluations and Stock Market Prices. Journal of Accounting Research, 13(2), 293-

Shafii, Z. Abdul Rahman, A.R (2016),"Issues on the application of IFRS9 and fair value measurement for Islamic financial instruments"

Strauss, A., \& Corbin, J. (2009). Dasar-Dasar Penelitian Kualitatif: Tata Langkah dan TeknikTeknik Teoritisasi Data. Yogyakarta: Pustaka Belajar.

Sukoharsono, E. G. (2006). Alternatif Riset Kualitatif Sains Akuntansi: Biografi, Phenomenologi, Grounded Theory, Critical Etnografi, dan Case Study. Analisa Ekonomi Makro dan Mikro: Jembatan Kebijakan Ekonomi Indonesia. BPFE Universitas Brawijaya. 230-236.

Suprayoga, F.D (2020). Konsep Kredibel dan Reliabel dalam Penilaian. Buletin Penilaian KPSPI MAPPI.

Tinker, T. (2004). "The Enlightenment and its discontents: Antinomies of Christianity, Islam and the calculative sciences"

Trokic, A. (2015). Islamic Accounting: History, Development and Prospects. European Journal of Islamic Finance, 3(12), 1-6.

Triyuwono, I. (2000). Akuntansi Syari'ah: Implementasi Nilai keadilan dalam Format Metafora Amanah. Jurnal Akuntansi dan Auditing Indonesia. 4(1): 1-34.

Triyuwono, I. (2003). Sinergi Oposisi Biner: Formulasi Tujuan Dasar Laporan Keuangan Akuntansi Syari'ah. Jurnal Of Islamic Economics. 4(1): 79-90.

Triyuwono, I. (2007). "Mengangkat "sing liyan" untuk Formulasi Nilai Tambah Syarieah". Simposium Nasional Akuntansi X Unhas, 26-28 Juli 2007. 1-21.

Triyuwono, I. (2013). So, what is Sharia Accounting?. Jurnal Ekonomi, Manajemen dan Akuntansi Islam. 1(1). 1-74

Triyuwono, I. (2013). Makrifat Metode Penelitian Kualitatif [dan Kuantitatif] Untuk Pengembangan Disiplin Akuntansi. Simposium Nasional Akuntansi Syariah. (September): $1-12$.

Triyuwono, I. (2015). Metode Penelitian Kualitatif di Bidang Pendidikan: Teori dan Aplikasinya. Malang: MNC Publishing.

Vandell, Kerry D. and Carter, Charles C. 2000. "Graaskamp's Concept of Highest and Best Use". In Sthephen P. Jarchow, ed., Appraisal, Market Analysis, and Public Policy in Real Estate: Essay in Honor of James A. Graaskamp. Boston: Kluwer and America Real Estate Society.

Ve'ron, N. (2008). Fair value accounting is the wrong scapegoat for this crisis. Accounting in Europe, 5, 63-69.

Whittred, G. and Y. Chan. 1992. Asset Revaluations and the Mitigation of Underinvestment.

Yin, R. K. (2013). Studi Kasus: Desain dan Metode. Jakarta: Rajawali Pers.

Yin, R. K. (2018). Studi Kasus: Desain dan Metode. Jakarta: Rajawali Pers.

Yoo, Choong-Yuek. Choi, Tae Hee. Pae, Jinhan. (2017). Demand for Fair Value Accounting: The Case of the Asset Revaluation Boom in Korea during the Global Financial Crisis

Zhai Y. H. (2007). Asset Revaluation and Future Firm Operating Performance: Evidence from New Zealand. Lincoln University. 
International Journal of Economics, Business and Accounting Research (IJEBAR)

Peer Reviewed - International Journal

Vol-4, Issue-3, 2020 (IJEBAR)

E-ISSN: 2614-1280 P-ISSN 2622-4771

https://jurnal.stie-aas.ac.id/index.php/IJEBAR

Zyla, M. L. (2009). Fair Value Measurements: Practical Guidance and Implementation. New Jersey: John Wiley \& Sons, Inc. 